\title{
The relationships between transforming growth factors $\beta$ and free thyroxine and progesterone in the ovarian cysts, preovulatory follicles, and the serum of sows
}

\author{
Tomasz Stankiewicz \\ West Pomeranian University of Technology, Szczecin, Faculty of Biotechnology and Animal Husbandry, \\ Department of Animal Reproduction Biotechnology and Environmental Hygiene, \\ 29 Klemensa Janickiego Street, 71-270 Szczecin, Poland \\ Correspondence to: Tomasz Stankiewicz(tomasz.stankiewicz@ zut.edu.pl)
}

Received: 28 October 2016 - Revised: 29 April 2017 - Accepted: 9 May 2017 - Published: 7 June 2017

\begin{abstract}
The aim of the study was to determine the relationships between bone morphogenetic protein 15 (BMP-15) and growth differentiation factor 9 (GDF-9) concentrations and free thyroxine ( $\left.\mathrm{FT}_{4}\right)$ and progesterone $\left(\mathrm{P}_{4}\right)$ concentrations in follicular cysts, preovulatory follicles, and the serum of sows (cyst-bearing $(n=26)$ and non-cyst-bearing $(n=26))$. $\mathrm{FT}_{4}$ and $\mathrm{P}_{4}$ concentrations were higher in the cystic fluid than in the fluid of preovulatory follicles ( $p<0.01$ and $p<0.05$ respectively). BMP-15 and GDF-9 concentrations were higher in the serum of cyst-bearing sows than non-cyst-bearing sows $(p<0.05)$ and higher in the cystic fluid than in the follicular fluid $(p<0.05)$. In the cysts and preovulatory follicles, GDF-9 concentration was higher than in serum $(p<0.01)$. FT 4 concentration in the serum of cystic sows was correlated with BMP-15 $(r=0.50, p<0.05)$ and GDF-9 $(r=0.62, p<0.01)$ concentrations in serum. In the serum of non-cyst-bearing sows, a positive correlation between $\mathrm{P}_{4}$ concentration and BMP-15 concentration $(r=0.60, p<0.01)$ was detected.

These data will help provide insight into the role of BMP-15, GDF-9, $\mathrm{FT}_{4}$, and $\mathrm{P}_{4}$ during cyst formation in sows.
\end{abstract}

\section{Introduction}

Ovarian cysts account for a major proportion of ovarian dysfunction (Cech and Dolezel, 2007; Szulańczyk-Mencel et al., 2010). In sows, polycystic ovaries cause reproductive disorders, reduce reproductive performance, and can result in their culling (Heinonen et al., 1998; Szulańczyk-Mencel et al., 2010). Despite much research, the etiopathogenesis of ovarian cysts is not yet fully understood. However, it is known that disturbances in hormonal regulation can cause ovarian cysts (Kozłowska et al., 2013). Thyroid hormones, as well as gonadotropins and steroid hormones, have important roles in the regulation of the porcine ovarian follicle function (Maruo et al., 1987; Gregoraszczuk et al., 1998) and are found in porcine ovarian follicular fluid (Stankiewicz et al., 2008). In in vitro experiments, thyroid hormones have been shown to affect steroidogenesis in porcine thecal and granulosa cells (Gregoraszczuk and Skalka, 1996). The participation of thy- roid hormones in the synthesis of steroid hormones is noted by influencing the activity of aromatase (Gregoraszczuk et al., 1998). It has been reported that thyroid hormones increase the impact of the follicle-stimulating hormone on the functional differentiation of cultured porcine granulosa cells (Maruo et al., 1987). In addition, thyroid hormone receptors, their mRNA, or both have been identified in porcine granulosa cells from preovulatory antral follicles (Maruo et al., 1992). Thyroid status has also been implicated in ovarian cyst formation in gilts (Fitko et al., 1995, 1996). Fitko et al. $(1995,1996)$ have shown that hypothyroidism increases the exogenous gonadotropin formation of cysts and weakens the steroidogenesis activity of ovaries in gilts. However, exactly how thyroid hormones contribute to the pathogenesis of ovarian cysts is unknown and might be based on interactions in the ovaries and the central or peripheral interrelations. It is possible that such interactions with thyroid hormones involve a bone morphogenetic protein 15 (BMP-15) 
and growth differentiation factor 9 (GDF-9), which belong to the transforming growth factor $\beta$ (TGF- $\beta$ ) superfamily. It is supposed that BMP-15 and GDF-9 are involved in hormonal regulation of the hypothalamic-pituitary-ovary axis (Paulini and Melo, 2011). These factors, depending on the stage of follicular development, may increase or weaken the influence of gonadotropins on the ovarian follicle (Knight and Glister, 2006; Crawford and McNatty, 2012). In addition, they influence the proliferation and differentiation of somatic cells of the follicle, steroidogenesis, deposition of the extracellular matrix, ovulation, and luteinization (Su et al., 2008; Orisaka et al., 2009; Peng et al., 2010). Also, recent work has suggested a role for BMP-15 and GDF-9 in the pathogenesis of follicular cysts in gilts and sows (Stankiewicz and Błaszczyk, 2014, 2016). However, the exact activity of BMP15 and GDF-9 in the pathogenesis of follicular cysts is unknown.

Therefore, the objective of the research was to identify differences and dependencies between BMP-15 and GDF9 concentrations and the concentrations of free thyroxine $\left(\mathrm{FT}_{4}\right)$ and progesterone $\left(\mathrm{P}_{4}\right)$ in follicular cysts, preovulatory follicles, and the serum of sows (cyst-bearing and non-cystbearing).

\section{Material and methods}

The study was carried out with Polish Large White $\times$ Polish Landrace crossbreds (from 2 to 3 years old) slaughtered at a local slaughterhouse. All sows were kept in a modern farm and then slaughtered in a modern, Polish slaughterhouse according to national legislation and in line with European Union legislation. At the time of slaughter, blood was collected from each sow's cervical vein into a serum separator tube. The blood was centrifuged at $1000 \times g$ for $15 \mathrm{~min}$, and the resulting serum was stored at $-20^{\circ} \mathrm{C}$ until analysed. During an ongoing slaughtering process, 52 sows were chosen for further examinations, including 26 sows with follicular cysts (cyst-bearing sows) and 26 sows without ovarian cysts but having preovulatory follicles (non-cyst-bearing sows). Each sow was assigned one fluid sample (from only one cyst or only one preovulatory follicle) and a corresponding serum sample. In the experiment, the following groups were distinguished for further research: follicular cysts $(n=26)$, preovulatory follicles $(n=26)$, serum of cyst-bearing sows $(n=26)$, and serum of non-cyst-bearing sows $(n=26)$. In order to obtain a uniform material, only bilateral polycystic ovaries were examined in the experiment. In polycystic ovaries, there were no corpora lutea and the current follicular structures with thin walls were filled with fluid and had a diameter of more than $21 \mathrm{~mm}$ (Heinonen et al., 1998; Cech and Dolezel, 2007; Sun et al., 2011). Ovaries in the preovulatory phase were identified as those having at least several follicles of the appropriate colour and composition, and they were 7 to $9 \mathrm{~mm}$ in diameter (Hunter et al., 2004; Paradis et al., 2009). In these ovaries a single corpus haemorrhagicum or corpus luteum was present. Ovaries with corpora albicantia were eliminated from the study (Babalola and Shapiro, 1988). The follicular/cystic fluid was aspirated with a needle and syringe from the preovulatory follicle/cyst. Fluid samples were centrifuged at $3000 \times g$ for $10 \mathrm{~min}$ to remove cellular material, and the supernatant was stored at $-20^{\circ} \mathrm{C}$ until being analysed.

\subsection{BMP-15 and GDF-9 assay}

Specimen-specific kits were used to determine the concentration of BMP-15 (Porcine BMP-15 ELISA kit, Novateinbio Biosciences, Cat. No. POR10362) and GDF-9 (Porcine GDF-9 ELISA kit, Novateinbio Biosciences, Cat. No. BGPOR11087). The test sensitivities were $0.1 \mathrm{ng} \mathrm{mL}^{-1}$ and $0.1 \mathrm{pg} \mathrm{mL}^{-1}$ for BMP-15 and GDF-9 respectively. The intraand inter-assay coefficients of variation were $<10 \%$ for BMP-15 and GDF-9. The measurement was conducted using a Wallac fluorometer 1420 VICTOR $^{2}$ (Wallac Oy, Turku, Finland). All assays were carried out in duplicate.

\section{$2.2 \mathrm{FT}_{4}$ and $\mathrm{P}_{4}$ assay}

$\mathrm{FT}_{4}$ concentrations were measured by fluoroimmunoassay using the Delfia ${ }^{\circledR} \mathrm{FT}_{4}$ kit (Perkin-Elmer, Wallac Oy, Finland) (Błaszczyk et al., 2006). The intra- and inter-assay coefficients of variation were 3.3 and $4.7 \%$ respectively. The sensitivity of the assay was $1.56 \mathrm{pg} \mathrm{mL}^{-1}$. The $\mathrm{P}_{4}$ concentration was also determined by fluoroimmunoassay using the Delfia ${ }^{\circledR} \mathrm{P}_{4}$ kit (Perkin-Elmer, Wallac Oy, Finland) (Stankiewicz et al., 2008, 2009; Błaszczyk et al., 2009). The intra- and inter-assay coefficients of variation were 4.9 and $6.9 \%$ respectively. The sensitivity of the assay was $0.25 \mathrm{ng} \mathrm{mL}^{-1}$.

All assays were carried out in duplicate. The measurements were made using a Wallac fluorometer 1420 VICTOR $^{2}$ (Wallac Oy, Turku, Finland).

\subsection{Statistical analysis}

The data are presented as an average \pm standard deviation of the mean and presented in the tables. Analysis of variance (ANOVA) and a post hoc test was done to identify statistically significant differences. Duncan's multiple range test was used to verify the significance of differences at $p<0.01$ and $p<0.05$. In addition, correlations between the analysed parameters were calculated with the Spearmen's rank correlation coefficient. Statistical analyses were conducted using the STATISTICA version 7.1, Stat Soft, Poland.

\section{Results}

Table 1 shows the mean concentrations of $\mathrm{FT}_{4}, \mathrm{P}_{4}$, BMP15 , and GDF-9 in cyst-bearing and non-cyst-bearing sows. 
Table 1. $\mathrm{FT}_{4}, \mathrm{P}_{4}$, BMP-15, and GDF-9 concentrations in the ovarian cystic fluid, preovulatory follicular fluid, and the serum of sows.

\begin{tabular}{|c|c|c|c|c|c|c|}
\hline & & \multicolumn{2}{|c|}{ Sows cysts-bearing $(n=26)$} & \multicolumn{2}{|c|}{ Sows non-cysts-bearing $(n=26)$} & \multirow[b]{3}{*}{ Statistical differences } \\
\hline & & Cystic fluid & Serum & Follicle fluid & Serum & \\
\hline Hormones & & 1 & 2 & 3 & 4 & \\
\hline $\mathrm{FT}_{4}\left(\mathrm{pg} \mathrm{mL} \mathrm{m}^{-1}\right)$ & mean $\pm \mathrm{SD}$ & $9.02 \pm 2.11$ & $8.46 \pm 1.92$ & $6.95 \pm 1.31$ & $7.05 \pm 1.48$ & 1,$3 ; p<0.01$ \\
\hline $\mathrm{P}_{4}\left(\mathrm{ng} \mathrm{mL}^{-1}\right)$ & mean $\pm \mathrm{SD}$ & $564.77 \pm 127.03$ & $3.49 \pm 1.71$ & $475.52 \pm 170.45$ & $2.54 \pm 1.43$ & $\begin{array}{l}1,2 ; p<0.01 \\
1,3 ; p<0.05 \\
3,4 ; p<0.01\end{array}$ \\
\hline BMP-15 (ng mL $\left.L^{-1}\right)$ & mean $\pm \mathrm{SD}$ & $1.95 \pm 0.98$ & $1.47 \pm 0.39$ & $1.08 \pm 0.70$ & $0.89 \pm 0.34$ & $\begin{array}{l}1,3 ; p<0.05 \\
2,4 ; p<0.05\end{array}$ \\
\hline GDF-9 (pg mL $\left.{ }^{-1}\right)$ & mean $\pm \mathrm{SD}$ & $23.99 \pm 4.87$ & $17.25 \pm 2.99$ & $19.08 \pm 3.23$ & $14.75 \pm 1.61$ & $\begin{array}{l}1,2 ; p<0.01 \\
1,3 ; p<0.05 \\
2,4 ; p<0.05 \\
3,4 ; p<0.01\end{array}$ \\
\hline
\end{tabular}

Table 2. Correlation coefficients $(r)$ between $\mathrm{FT}_{4}$ and $\mathrm{P}_{4}$ concentrations and the concentration of the transforming growth factors (BMP-15 and GDF-9) in the cystic fluid and serum of cyst-bearing sows $(n=26)$.

\begin{tabular}{lrrrr}
\hline Parameter & $\mathrm{FT}_{4}$ in serum & $\mathrm{FT}_{4}$ in cystic fluid & $\mathrm{P}_{4}$ in serum & $\mathrm{P}_{4}$ in cystic fluid \\
\hline BMP-15 in serum & $0.50^{*}$ & 0.23 & -0.09 & 0.12 \\
BMP-15 in cystic fluid & 0.02 & 0.06 & -0.18 & 0.14 \\
GDF-9 in serum & $0.62^{* *}$ & 0.13 & 0.12 & 0.20 \\
GDF-9 in cystic fluid & 0.11 & 0.18 & -0.17 & 0.11 \\
\hline
\end{tabular}

Values marked $*$ and ${ }^{* *}$ are significant at $p<0.05$ and $p<0.01$ respectively.

The $\mathrm{FT}_{4}$ concentration in the serum of cyst-bearing sows was not statistically different from its in-cyst concentration. Also, $\mathrm{FT}_{4}$ concentration did not differ between the serum and preovulatory follicles of non-cyst-bearing sows nor were any differences found between the $\mathrm{FT}_{4}$ concentration in the serum of cyst-bearing sows and non-cyst-bearing sows. However, the $\mathrm{FT}_{4}$ concentration in the cystic fluid was significantly higher than in the fluid of preovulatory follicles.

In cyst-bearing and non-cyst-bearing sows, the $\mathrm{P}_{4}$ concentration was significantly higher in the ovary structures (cysts and preovulatory follicles) than in the serum. Also, $\mathrm{P}_{4}$ concentration was significantly higher in cysts than in preovulatory follicles.

BMP-15 and GDF-9 concentrations were significantly higher in the serum of cyst-bearing than in that of non-cystbearing sows. BMP-15 and GDF-9 concentrations were also higher in the cystic fluid than in follicular fluid. BMP-15 concentration in the preovulatory follicles did not differ significantly from its concentration in serum. However, these values did differ for GDF-9. In the preovulatory follicles, GDF9 concentration was significantly higher than in the serum. Similar differences were found in cyst-bearing sows. BMP15 concentration in cysts did not differ significantly from its concentration in serum. However, GDF-9 concentration in cysts was significantly higher than in serum.
Tables 2 and 3 show the correlation coefficients between $\mathrm{FT}_{4}, \mathrm{P}_{4}$, and transforming growth factors $\beta$ in cyst-bearing and non-cyst-bearing sows. In the serum of cystic sows, the $\mathrm{FT}_{4}$ concentration was positively and significantly correlated with BMP-15 and GDF-9 concentrations. In non-cystbearing sows, a positive and significant correlation was found between serum $\mathrm{P}_{4}$ and BMP-15 concentrations.

\section{Discussion}

Studies on the pathogenesis of ovarian cysts must consider many potential contributing factors (Fitko et al., 1995, 1996; Kozłowska et al., 2013; Pierre et al., 2016). As such, it is not yet possible to exclude contributions by BMP-15 and GDF9 during cyst formation (Stankiewicz and Błaszczyk, 2014, 2016). Increased BMP-15 and GDF-9 concentrations were found in the follicular cysts of gilts and sows (Stankiewicz and Błaszczyk, 2014, 2016). Here, I detected higher BMP-15 and GDF-9 concentrations in the cystic fluid than in follicular fluid. However, these differences were smaller than in earlier work (Stankiewicz and Błaszczyk, 2014, 2016). Nevertheless, the presence of BMP-15 and GDF-9 in the follicular and cystic fluid confirms that these factors create the proper follicular microenvironment and can participate in the development of follicular cysts. In addition, BMP-15 and GDF-9 concentrations are positively correlated in follicular fluid and 
Table 3. Correlation coefficients $(r)$ between $\mathrm{FT}_{4}$ and $\mathrm{P}_{4}$ concentrations and the concentration of the transforming growth factors (BMP-15 and GDF-9) in the preovulatory follicle fluid and serum of non-cysts-bearing sows $(n=26)$.

\begin{tabular}{lrrrr}
\hline Parameter & $\mathrm{FT}_{4}$ in serum & $\mathrm{FT}_{4}$ in follicle fluid & $\mathrm{P}_{4}$ in serum & $\mathrm{P}_{4}$ in follicle fluid \\
\hline BMP-15 in serum & 0.28 & 0.20 & $0.60^{*}$ & 0.19 \\
BMP-15 in follicle fluid & 0.39 & 0.35 & 0.24 & -0.18 \\
GDF-9 in serum & 0.02 & -0.05 & -0.01 & -0.24 \\
GDF-9 in follicle fluid & -0.14 & -0.11 & 0.31 & 0.40 \\
\hline
\end{tabular}

Values marked $*$ are significant at $p<0.01$

serum (Stankiewicz and Błaszczyk, 2016). Thus, I cannot exclude their participation in the peripheral control of folliculogenesis.

As shown here, the concentration of BMP-15 and GDF9 in serum is higher in cyst-bearing than non-cyst-bearing sows, which is in line with previous studies (Stankiewicz and Błaszczyk, 2016). Unlike in previous studies, in the current study it was also found that GDF-9 concentration was higher in the cystic and follicular fluid than in serum. The higher concentrations in the cystic and follicular fluids show, that the synthesis of transforming growth factors such as GDF9 and BMP-15 occurs in ovarian follicles at various stages of development. According to Fitzpatrick et al. (1998) and Knight and Glister (2006), the expression of GDF-9 mRNA was found in the hypothalamus, pituitary, and uterus of different mammalian species, so that theses extraovarian organs can also influence the serum levels. The exact role of BMP-15 and GDF-9 in the pathogenesis of follicular cysts is unknown. Therefore, in the present study, I aimed to define the relationships between these and other factors that might participate in the formation of follicular cysts. One of such factor is the steroidogenic activity of the ovarian follicle. Disturbed follicular steroidogenesis is either an effect or a cause of ovarian disorders, such as ovarian cysts (Babalola and Shapiro, 1990; Szulańczyk-Mencel et al., 2010). Here, higher levels of $\mathrm{P}_{4}$ were found in the cystic fluid than in preovulatory follicle fluid, which is in line with previous studies (Babalola and Shapiro, 1990; Kozłowska et al., 2013) and could be due to luteinization spontaneously beginning in non-ovulating, cystic follicles. However, the absence of any difference between the serum concentrations of $\mathrm{P}_{4}$ in the serum of cyst-bearing and non-cyst-bearing sows confirms that the hormonal abnormalities in the follicular cysts are not reflected in the serum profiles of this steroid (Babalola and Shapiro, 1990). It is interesting that the concentration of $\mathrm{P}_{4}$ was positively correlated with BMP- 15 concentration in the serum of sows without follicular cysts. Based on this finding, I propose that the interactions between BMP-15 and progesterone are involved in the control of folliculogenesis in sows.

Thyroid hormones have also been suggested as participating in folliculogenesis and/or the formation of follicular cysts (Fitko et al., 1996; Błaszczyk et al., 2006; Stankiewicz et al., 2008). I tested the concentration of $\mathrm{FT}_{4}$, which is a more reliable indicator of thyroid status than total thyroxine concentration (Nowak, 1983). Here, I found no differences between the concentration of $\mathrm{FT}_{4}$ in the serum of cyst-bearing and non-cyst-bearing sows, and the recorded concentration of this hormone in the serum of the examined sows was similar to concentrations observed in pigs (Spiegel et al., 1993). Thus, neither the non-cyst-bearing nor the cyst-bearing sows in this study displayed hypo- or hyperthyroidism. In contrast, Fitko et al. (1995) reported that the hypothyroid status of gilts intensifies the cyst-formative actions of extrapituitary gonadotropins, whereas hyperfunctioning of the thyroid significantly reduces this response. The authors of that study also suggested that the mechanism of these antagonist relations may be based on the interaction between receptors for thyroid hormones and gonadotropins in the ovary and/or on the central or peripheral relationship between thyroid hormone and estrogens (Fitko et al., 1995). The results of this study indicate a possible local activity of thyroid hormones during the formation of ovarian cysts because the concentration of $\mathrm{FT}_{4}$ was significantly higher in the cysts than in preovulatory follicles. Moreover, despite a similar concentration of $\mathrm{FT}_{4}$ in the serum of cyst-bearing and non-cystbearing sows, I cannot exclude peripheral effects of thyroid hormones in the pathogenesis of follicular cysts in pigs. In the present study shown positive correlations between $\mathrm{FT}_{4}$ and BMP-15 and GDF-9 in the serum of cyst-bearing sows have been. The participation of BMP-15 and GDF-9 in the pathogenesis of follicular cysts in pigs has been suggested (Stankiewicz and Błaszczyk, 2014, 2016). In addition, these factors, depending on the stage of folliculogenesis, can either strengthen or weaken the influence of gonadotropins on the ovarian follicle (Knight and Glister, 2006; Crawford et al., 2012). Also, the interactive effect of thyroid hormones and gonadotropins on the formation of follicular cysts has been shown in gilts (Fitko et al., 1995, 1996). Therefore, the relationships between BMP-15, GDF-9, and $\mathrm{FT}_{4}$ in cyst-bearing sows may be associated with a control of gonadotropins. This is a possible pathway for the action of BMP-15, GDF-9, and $\mathrm{FT}_{4}$ in the mechanism of the formation of follicular cysts in sows. 


\section{Conclusion}

The data presented here will be useful for investigations into the potential roles of the transforming growth factor $\beta$, thyroxine, and progesterone during the formation of follicular cysts in sows.

Data availability. The original data are available upon request from the corresponding author.

Competing interests. The author declares that he has no conflict of interest.

Edited by: M. Mielenz

Reviewed by: two anonymous referees

\section{References}

Babalola, G. O. and Shapiro, B. H.: Correlation of follicular steroid hormone profiles with ovarian cyclicity in sows, J. Reprod. Fert., 84, 79-87, 1988.

Babalola, G. O. and Shapiro, B. H.: Sex steroid changes in porcine cystic ovarian disease, Steroids, 55, 319-324, 1990.

Błaszczyk, B., Stankiewicz, T., Udała, J., and Gączarzewicz, D.: Plasma progesterone analysis by a time-resolved fluorescent antibody test to monitor estrous cycles in goats, J. Vet. Diagn. Invest., 21, 80-87, 2009.

Błaszczyk, B., Stankiewicz, T., Udała, J., Gączarzewicz, D., Lasota, B., Błaszczyk, P., Szymańska, A., and Szymańska-Pasternak, J.: Free thyroid hormones and cholesterol in follicular fluid of bovine ovaries, Bull. Vet. Inst. Pulawy., 50, 189-193, 2006.

Cech, S. and Dolezel, R.: Treatment of ovarian cysts in sows - a field trial, Vet. Med.-Czech., 52, 413-418, 2007.

Crawford, J. L. and McNatty, K. P.: The ratio of growth differentiation factor 9: bone morphogenetic protein 15 mRNA expression is tightly coregulated and differs between species over a wide range of ovulation rates, Mol. Cell. Endocrinol., 348, 339-343, 2012

Fitko, R., Kucharski, J., and Szlezyngier, B.: The importance of thyroid hormone in experimental ovarian cyst formation in gilts, Anim. Reprod. Sci., 39, 159-168, 1995.

Fitko, R., Kucharski, J., Szlezyngier, B., and Jana, B.: The concentration of GnRH in hypothalamus, LH and FSH in pituitary, LH, PRL and sex steroids in peripheral and ovarian venous plasma of hypo- and 15 hyperthyroid, cysts-bearing gilts, Anim. Reprod. Sci., 45, 123-138, 1996.

Fitzpatrick, S. L., Sindoni, D. M., Shughrue, P. J., Lane, M. V., Merchenthaler, I. J., and Frail D. E.: Expression of growth differentiation factor-9 messenger ribonucleic acid in ovarian and nonovarian rodent and human tissues, Endocrinology, 139, 2571-2578, 1998.

Gregoraszczuk, E. L. and Skalka, M.: Thyroid hormone as a regulator of basal and human chorionic gonadotrophin-stimulated steroidogenesis by cultured porcine theca and granulosa cells isolated at different stages of the follicular phase, Reprod. Fertil. Dev., 8, 961-971, 1996.
Gregoraszczuk, E. L., Słomczynska, M., and Wilk, R.: Thyroid hormone inhibits aromatase activity in porcine thecal cells cultured alone and in coculture with granulosa cells, Thyroid, 8, 11571163, 1998.

Heinonen, M., Leppävuori, A., and Pyörälä, S.: Evaluation of reproductive failure of female pigs based on slaughterhouse material and herd record survey, Anim. Reprod. Sci., 52, 235-244, 1998.

Hunter, M. G., Robinson, R. S., Mann, G. E., and Webb, R.: Endocrine and paracrine control of follicular development and ovulation rate in farm species, Anim. Reprod. Sci., 82-83, 461-477, 2004.

Knight, P. G. and Glister, C.: TGF- $\beta$ superfamily members and ovarian follicle development, Reproduction (Cambridge, England), 132, 191-206, 2006.

Kozłowska, A., Wojtkiewicz, J., Majewski, M., and Jana, B.: The noradrenergic innervation and steroidogenic activity of porcine cystic ovaries, Physiol. Res., 62, 421-433, 2013.

Maruo, T., Hayashi, M., Matsuo, H., Yamamoto, T., Okada, H., and Mochizuki, M.: The role of thyroid hormone as a biological amplifier of the actions of follicle-stimulating hormone in the functional differentiation of cultured porcine granulosa cells, Endocrinology, 121, 1233-1241, 1987.

Maruo, T., Hiramatsu, S., Otani, T., Hayashi, M., and Mochizuki, M.: Increase in the expression of thyroid hormone receptors in porcine granulosa cells early in follicular maturation, Acta Endocrinol. (Copenh.), 127, 152-160, 1992.

Nowak, G.: Free thyroid hormone levels during the postnatal period in the pig, Biol. Neonate., 43, 164-171, 1983

Orisaka, M., Jiang, J. Y., Orisaka, S., Kotsuji, F., and Tsang, B. K.: Growth differentiation factor 9 promotes rat preantral follicle growth by upregulating follicular androgen biosynthesis, Endocrinology, 150, 2740-2748, 2009.

Paradis, F., Novak, S., Murdoch, G. K., Dyck, M. K., Dixon, W. T., and Foxcroft, G. R.: Temporal regulation of BMP2, BMP6, BMP15, GDF9, BMPR1A, MPR1B, BMPR2 and TGFBR1 mRNA expression in the oocyte, granulosa and theca cells of developing preovulatory follicles in the pig, Reproduction, 138, 115-129, 2009.

Paulini, F. and Melo, E.: The role of oocyte-secreted factors GDF9 15 and BMP15 in follicular development and oogenesis, Reprod. Dom. Anim., 46, 354-361, 2011.

Peng, X., Yang, M., Wang, L., Tong, C., and Guo, Z.: In vitro culture of sheep lamb ovarian cortical tissue in a sequential culture medium, J. Assist. Reprod. Genet., 27, 247-257, 2010.

Pierre, A., Estienne, A., Racine, C., Picard, J.-Y., Fanchin, R., Lahoz, B., Alabart, J. L., Folch, J., Jarrier, P., Fabre, S., Monniaux, D., and di Clemente, N.: The bone morphogenetic protein 15 up regulates the anti-Müllerian hormone receptor expression in granulosa cells, J. Clin. Endocrinol. Metab., 101, 2602-2611, 2016.

Spiegel, C., Bestetti, G. E., Rossi, G. L., and Blum, J. W.: Normal circulating triiodothyronine concentrations are maintained despite severe hypothyroidism in growing pigs fed rapeseed presscake meal, J. Nutr., 123, 1554-1561, 1993.

Stankiewicz, T. and Błaszczyk, B.: Concentrations of bone morphogenetic protein-15 (BMP-15) and growth differentiation factor-9 (GDF-9) in follicular cysts, mono- and polyoocyte follicles in gilts, Acta Vet.-Beograd., 64, 24-32, 2014. 
Stankiewicz, T. and Błaszczyk, B.: Relationship between the concentration of bone morphogenetic protein-15 (BMP-15) and growth differentiation factor-9 (GDF-9) in pre-ovulatory follicles, ovarian cysts, and serum in sows, Anim. Prod. Sci., 56, 141-146, 2016.

Stankiewicz, T., Błaszczyk, B., Lasota, B., Gączarzewicz, D., and Udała, J.: Saisonabhängige Veränderungen der Ovargröße sowie Konzentration von Steroidhormonen und Thyroxin in der Follikelflüssigkeit beim Schwein, Tierarztl. Prax., 36, 99-103, 2008.

Stankiewicz, T., Błaszczyk, B., and Udała, J.: A Study on the occurrence of polyovular follicles in porcine ovaries with particular reference to intrafollicular hormone concentrations, quality of oocytes and their in vitro fertilization, Anat. Histol. Embryol., 38, 233-239, 2009.
Su, Y. Q., Sugiura, K., Wigglesworth, K., O’Brien, M. J., Affourtit, J. P., Pangas, S. A., Matzuk, M. M., and Eppig, J. J.: Oocyte regulation of metabolic cooperativity between mouse cumulus cells and oocytes: BMP-15 and GDF-9 control cholesterol biosynthesis in cumulus cells, Development, 135, 111-121, 2008.

Sun, Y. L., Ping, Z. G., Li, C. J., Sun, Y. F., Yi, K. L., Chen, L., Li, X. Y., Wang, X. L., and Zhou, X.: Comparative proteomic analysis of follicular fluids from normal and cystic follicles in sows, Reprod. Dom. Anim., 46, 889-895, 2011.

Szulańczyk-Mencel, K., Rząsa, A., and Bielas, W.: Relationships between ovarian cysts and morphological and hormonal state of ovarian cortex in sows, Anim. Reprod. Sci., 121, 273-278, 2010. 